\title{
The Reality of Child Labor in Industry Based on "Putting-Out" System from Sustainable Development Perspective
}

\author{
Bambang Harjono $^{1}$, Arianti Ina Restianti Hunga ${ }^{2}$, Daniel Daud Kameo ${ }^{3}$ \\ \{bharjono08@gmail.com; ina.hunga@uksw.edu*; ddkameo@yahoo.com\} \\ ${ }^{1}$ Doctoral Student in Developmental Studies - Interdisciplinary Faculty, Universitas Kristen Satya Wacana \\ ${ }^{2,3}$ Interdisciplinary Faculty, Universitas Kristen Satya Wacana
}

\begin{abstract}
Statistics show that the trend of child labor decreases, however, several studies find that child labor increases especially in informal sector. Child labor in informal sector is included within home-based industry or putting-out system (POS). Child labor becomes a controversial issue because it is against the rights for children. However, the fact remains that children are involved in works for economic reasons and the involvement also becomes a form of learning the inheritance of local knowledge and culture-based businesses. Such phenomenon can be found in home-based industries, for example batik, weaving, and other culture-based handicrafts industry. The involvement of child labor in these sub-sectors is also controversial because their involvement is marginalized. This paper aims to explain (1) the reality of child labor and the fulfilment of child rights in Indonesia, (2) the condition of child labor in industries with putting-out system, and (3) child labor in sustainable development. This research is conducted by applying scoping study method with secondary data. Child labor in POS-based industry is an opportunity because it happens within domestic sphere and integrates with a family-based business. Their involvement is a tug-of-war between the fulfilment of child rights and the economic and socio-cultural aspects in the context of inheriting local knowledge.
\end{abstract}

Keywords: child labor, commoditization, informal, putting-out system

\section{Research Background}

Globally, child labor shows a declining trend, which is shown through year range data. In 2000, there were 246 million child laborers. This number decreased to 222 million in 2004, and continued to decrease to 215 million in 2008, 168 million in 2012, and 152 million in 2016. In particular, in 2016, from 152 million child laborers, 70 percent were in 5-17 years age range. The data on child laborers aged 5-17 years old in Indonesia showed the same trend in 2012-2019. In 2012, there were 9.43 percent, and it decreased to 5.99 in 2015. However, in 2016, the percentage of children labor increased again to 6.99 percent and 7.23 percent in 2017. The number, however, decreased to 7.05 percent in 2018 [1]. The attention to child labor becomes relevant when it is related to the projected population of National Central Statistics Agency (Badan Pusat Statistik Nasional/BPS) [2] which explained that 30.1 percent or 79.55 million people of Indonesia were children of 0-17 years old. This means that one out of every three Indonesians are children. In the next few years, it is projected that the number of children in Indonesia will not experience significant changes.

The phenomenon of child labor at the global level shows that 71 percent of children work in agricultural sector, 12 percent in manufacturing industry, and 17 percent in service sector [3]. Out of these numbers, only $1 / 5$ (one fifth) of child laborers receive wages. The majority of child workers work in a family environment, so they are not paid. This means that around 70 million (out of 129 million) child laborers are in hazardous work. In Indonesia, the practice of child labor spreads across various sectors. In rural areas, the largest distribution lies in the agricultural sector with 60 percent, industrial and labor sectors at 18 percent, trade at 10 percent, services at 3.5 percent, and others at 9.5 percent. In urban areas, the largest number lies in the industrial sector (operators and workers) by 31.3 percent, the trade sector with 23 percent, the service sector with 14.6 percent, the agricultural sector by 11.3 percent, and the remaining 19.8 percent is other industries [4].

The decline in the number of child workers can be attributed to two things. The first one is global and national movements for the promotion to the fulfillment of children's rights, which is demonstrated by the commitment of many countries to ratify the Convention on the Rights of the Child. In particular, in 2002, Indonesia issued a Presidential Decree prohibiting child labor from working in hazardous industries (Presidential Decree No 59 of 2002) and Law No 13 of 2003 in Articles 68-75 prohibiting child labor. And secondly, the released child labor data were data taken from formal sectors as a consequence of the prohibition of child labor 
and the fulfillment of children's Rights. This was mentioned in the Law No 4 of 1979, Law No 39 of 1999 on Human Rights, Law 23 of 2002 concerning Child Protection [5]. In this case, it is suspected that child workers from formal sectors shift to informal sector.

In general, there are two groups of debates related to child labor. The first group opposes child labor by considering the violation of children's rights and the fact that child exploitation will affect the loss of schooling opportunities, low and unpaid wages, and relatively long working hours. The second group accepts child labor by paying attention to the dilemma of poverty, fulfillment of children's basic rights, inheritance process of local knowledge, and training process to prepare for children's independence. One of White's research findings [6] shows that in Javanese rural communities, children have been involved in agricultural, household and other chores as laborers since they were quite young. In this case, the child actually works as a learning process, transfers knowledge, and acquires local values in the life of agricultural community. Besides being involved in the agriculture sector, they are also involved in local knowledge-based industries such as batik and weaving. These are inheritable industries, passed down between generations, and developed into a family identity. Most of these traditional industries are based at home [7], [8]. Furthermore, these industries tend to be informal and is unapproachable by the regulation and strict supervision of industrial relations practices as is the case of formal sector [9], [10].

Based on the above explanation, it is an interesting phenomenon to see child labor as a tug-of-war between the fulfillment of the children's rights and the fulfillment of other aspects, for example economic and socio-cultural as a form of inheritance or the continuation of local knowledge. Therefore, this paper aims to explain (1) the reality of child labor and the fulfilment of child rights in Indonesia, (2) the condition of child labor in industries with putting-out system, and (3) child labor in sustainable development.

\section{Research Method}

The study uses scoping study method by taking secondary data obtained from literatures and previous research. They are then analyzed according to the purpose and adequacy of the data obtained. Then, the study is complemented with further investigation and in-depth discussions based on the already established topics [11], [12].

This step starts by identifying the research questions and the parts need to be explored. The next step is finding relevant studies and gathering information through electronic databases, reference lists (derived search), organizational websites, conference processes. Then, it is followed by selecting relevant studies related to research questions, compiling data charts (i.e., information from relevant studies), arranging, summarizing, and making report based on the results. The final step is to consult with stakeholders such as policy-making professionals or whoever with expertise in the area to acquire more references and able to provide insight into any missing information from the acquired literatures [13].

\section{Results and Discussion}

This sub-chapter will explain three main topics of discussion: (1) the reality of child labor and the fulfilment of child rights in Indonesia, (2) the condition of child labor in industries with putting-out system, and (3) child labor in sustainable development.

\subsection{The Reality of Child Labor and the Fulfilment of Children's Rights}

Before the author discusses the reality of child labor, the author will explain the definition of child labor. In general, the International Labor Organization (ILO) [14] defines child labor as children who help their parents do any work to earn money, the activities are considered as work regardless of the form of work and its hazardous aspect. In the context of age restrictions, ILO [14] defines child labor as children aged 5-17 years old, who are involved in helping their parents to do work that earns money. The determination of the limit of 17 year old, as previously indicated, is by considering the existing laws and regulations. On the other hand, the lowest age limit, 5 years old, was chosen based on the fact that it is rare for children under 5 years old to be involved in employment in Indonesia [15].

In the context of the reality of child labor, globally, child labor experiences many negative impacts as a consequence of their work. In general, these impacts can be categorized into direct impact on child labor and their families, and indirect impact, which include any negative impacts of the existence of child labor within the country and the world level. According to ILO [3], negative impacts on child labor include negative effect towards physical and mental health, lost school opportunities, and the decreased opportunities for acquiring better future occupation. Another negative impact for the families of child workers also include chronic illness and disability in old age, increasing the likelihood of child labor for future generations, and persisting poverty 
due to consistent working with low wages. Negative impacts for the country itself consist of lower health quality for adult workers, unskilled workers, low wages, and socially fragile and marginalized worker groups. The last negative impacts in the world level include low labor productivity, inability to compete in working environment, and vulnerability to face economic problems in global migration.

The same reality is experienced by child workers in Indonesia. According to Agustine et al. [16], although the data has showed a decline on the trend of child labor, this still does not reduce the urgency of efforts to eliminate child labor, both in national and global level. This is caused by the fact that child workers still experience and face the reality of poor working conditions such as low wages and long working hours [17]. In 2015, the spread of child labor in Indonesia covered various sectors such as 61.6 percent in the agricultural sector, 26.5 percent in the service sector, and 12 percent in the industrial sector. In reality, in some of the above sectors, there are also child laborers involved in the production and sale of illegal drugs, often suffered from human trafficking, involved in commercial sex exploitation, therefore, regulations is significant to protect child labor [16]. Furthermore, data from the Ministry of Labor [18] shows that out of the total number of child laborers in Indonesia, 52.72 percent lived in cities and 47.28 percent of them lived in rural areas. Based on the data on child labor, the majority of child workers, namely around 90 percent of child laborers do not attend school. Therefore, in this case, the child's right to acquire good education is not fulfilled.

Currently, there are three different perspectives on looking at child labor issue. They are work-free childhood perspectives, socio-cultural perspectives, and political economy perspectives [15], [19]. Work-free childhood perspective sees that children are not supposed to work, as they are only to play and study. Based on this perspective, children are not permitted and burdened to work. Children are seen as social responsibility of their parents, family, community, and even the state. Therefore, children must be protected because they are vulnerable to exploitation. Children are the future human capital who need to have the opportunity to grow and achieve their optimal capacity. Based on socio-cultural perspective, it is necessary for children to be enabled, even though they become child labor, which aims to prepare and teach them or empowering them within the domestic sphere so that children could inherit the work ethics and local knowledge from their families. Such practice of child labor is often found in industries such as batik, woven cloth, dance, domestic work, and so on [15], [18]-[20]. Political and economy perspective emphasizes child labor in the ecological, economic and political context. The regulation regulates that child labor is not related and becomes a victim of industries that are not environmentally friendly, dangerous, and exploiting because children need economic wages for family income. Finally, the protection approach (economic politics) and empowerment (socio-cultural) must co-exist with the perspective of work-free childhood. This is done to prevent children from dealienation if empowerment programs are conducted appropriately and proportionally [15], [19]. Out of the three perspectives above, the combination of socio-cultural and political perspective is the most commonly found notion in communities, especially in developing countries, such as Indonesia.

In fact, relevant institutions has formulated the fulfillment of children's rights, in relation to all children in the world and child labor. For example, an independent institution, Wahana Visi Indonesia [21] launched a list of the rights of children, such as (1) the rights to grow or developmental rights that children should not suffer from malnutrition, (2) the rights for participation or participation right that children are not to be excluded simply because they are children, and they have the rights to participate and voice their opinions, (3) the rights for protection rights or protection right, in which children are considered to be weak and not strong enough to support themselves, therefore they should be protected by adults; within the context of child labor, if the work endanger the child, this would be against the protection rights, and (4) the right to a more decent life, or survival right, in which the life of future generations (in this case, children) must always be better than the lives of their previous generations.

In the efforts to oversee and safeguard the fulfillment of children's rights, the government established state institutions specifically for the protection of the rights such as the Indonesian Child Protection Commission (KPAI) and the National Commission on Human Rights in Indonesia. In addition, Indonesia also ratified Law No. 23 of 2002. This Law contains and regulates the protection of children's rights, consisting of 93 articles. Articles 1-4 contain the basis for child protection, and subsequent articles cover the rights and obligations of children, including who is responsible for fulfilling children's rights, or issues relating to children and children's rights.

However, on the other hand, child labor cannot only be seen through the perspective of economy and poverty. From socio-cultural aspect, children who work or are involved in family work is an ongoing condition and it is hereditary. For example, in agriculture, the involvement of family workers including children, has become a daily life for families of farmer [22]. Likewise, it is a similar condition in manufacturing industries based on local knowledge, such as batik, weaving, traditional food and other industries in Indonesia [23]. In Chinese families, the involvement of children in family businesses is a must [24]. Based on these facts, the 
involvement of children as a family-based business or home-based industry is a longstanding fact in the lives of Indonesian people. In the rural context, for example, it has become commonplace since colonial times for parents to employ boys to help cultivate agriculture and girls are given the task of helping with household chores [25]. White [6] reveals that the involvement of child labor as a form of inheritance of knowledge and skills as a business and even as a family identity has commonly occurred in Indonesia. That is the reason the term child labor appears to be accepted by the community as a positive thing and views child labor as a learning process in building character as a whole and holistic human being.

The results of the research described above show that child labor is a complex problem. However, in understanding child labor, it should be placed in the context of the community and family because most children still live within the family sphere. We should also look at the family context from both economic and sociocultural aspects. Despite the fact that some of the child laborers come from poor families, many of these families expect wages from working children or reduce wages to increase family income. Furthermore, the involvement of children as workers is not entirely caused by economic motivation. In this case, active child laborers or parents involving children in work with wage is an attempt to prepare their children's independence, and as a process of transfer of knowledge to prepare children to continue (as the heirs) of the family business. These are example of cases in which wage is not a motivation because they are not from poor families. We can find such cases in batik business in Pekalongan. Similar situations also occur in most businesses in the rural agricultural sector, in which agricultural regeneration is a challenge, young people are not interested in farming and prefer to work in urban industries. Some people finally attempt to encourage more participation by introducing farming business to children during early childhood [6].

In this context, child labor can certainly be seen through the context of access and opportunities to fulfill the children's right to knowledge and inheritance for the future. However, if seen through the context of human rights, child labor does not eliminate the opportunity for growth, education, play, and other rights for children. Therefore, the issue of child labor is placed in the intersection of economic, socio-cultural, and political aspects. In relation to the realities faced by child labor, it can be concluded that even though there have been efforts made by institutions including state institutions and regulations, this cannot guarantee the complete fulfillment of children's rights, especially within the context of child labor due to its complexity as associated within the community context.

\section{2) The Condition of Child Labor in Industries with Putting-out System}

Before describing the conditions of child labor in "Putting-Out System" (POS) industry, it is important to first describe POS industry itself. According to ILO [3], POS is a production system in which most of the production process is outside the company or at home or a place chosen by its employees, and takes place without or very little supervision from the employer or company. Therefore, seen through its main characteristics, it can be concluded that POS industry is an informal industry. Such production system uses workers known as homebased workers or home-workers (hereinafter abbreviated as HW). HW differs from factory workers in many important aspects, for example: they do not have corporate work ties, so work relationships is conducted informally; flexible working hours; no wage standard which tends to be very low; unsafe and unhealthy working conditions; these factors tend to place workers into a weak position and exploitation [9], [10], [17]. Furthermore, HW and POS industry are not accommodated in labor policies and industrial employment relations, such as in Law No 13 of 2003. Consequently, the protection and certainty of fulfilling the rights of homeworkers, including child labor, is not guaranteed well. Employers or intermediaries are not charged with the obligation to meet workers' eligibility standards, as well as providing occupational health and safety protection. In many cases, child workers must bear various risks caused by their involvement in home work [26]. Thus, the existence of child labor in these businesses is invisible, and have higher tendency to be hidden and further exploited [9], [10].

Based on Hunga's [10] findings, the characteristics of the POS industry in Indonesia are (1) based on local knowledge such as making batik, weaving handicrafts, carving crafts, and traditional food manufacturing, (2) the work ties is based on patron-client relations, (3) a part of family identity so that it is maintained from generation to generation. The problem remains that POS-based industries vary widely and it determines the character of involvement of workers from family members, including children. Hunga [10] classifies POS-based industries into three types. The first type is local knowledge-based POS industries that apply "slow" production, which is the production of products with philosophical value, rely on hand or non-machine skills, have relatively strong local characteristics, and use natural colors. Such industries are found in traditional and printing batik industry, especially those maintaining natural colors and traditional designs, traditional weaving, and other industries that still retain traditional values. These industries are mostly hereditary industries and involve family workers, including children, who are already involved during their early childhood. The second type is industries with relatively strong and broad market penetration, in which they apply rapid and mass production, combine humans 
and machinery as its industry support, lack of local content, could be easily replicated, not environmentally friendly, and economic-oriented. Industries like this can be seen in batik textile industry, semi-machine and machine-produced weaving industry, garment industry, and so on. The third type is a combination of both. The characters of POS-based industry determines the involvement of family workers including children, and their working conditions. In the second and third type of POS industry, HW and family workers (including children and the elderly) are sources of workers who can be paid cheaply and help businesses to reduce production costs, and they could sell at lower prices to achieve higher sales. In such POS-based industries, the condition of child laborers becomes extremely worrying because they are treated as workers and acquire low wage, furthermore, they are threatened to lose their job if they waste time by attending school. On the other hand, the first type of POS-based industry has better condition for child laborers. They are involved in production process for the sake of education, character building, and inheriting local knowledge [10].

Therefore, from the perspective of looking at child labor above, there seems to be a paradox in the involvement of child labor in POS-based industry. On one hand, the economic and financial needs of the child workers' family are the main needs that must be met immediately. As the consequence, children must work in industrial sector or informal businesses such as POS while suffering from marginalization and exploitation. On the other hand, if observed through its social and cultural aspects, the existence and involvement of child labor also has positive effects such as the transfer or inheritance of knowledge, skills, and self-identity as well as family identity from parents. Furthermore, it could also be used as a means and opportunity for children to learn to work, to be independent, and to shape their own character to become better individual. In the context of macroeconomic system and in the context of facing globalization challenges, the existence of workers such as informal labor and family workers including children in POS-based industry becomes strategic amidst the national-global economic system that increasingly shifts to more flexible businesses and networking-based and informal business relations.

\subsection{Child Labor in POS Industry in Sustainable Development Context}

Before discussing the related topics further, it is important to also discuss the perspective of sustainable development. The most fundamental idea of sustainable development is the effects of development which could worsen human conditions, increase poverty, reduce the quality of natural resources, and reduce the quality of the surrounding environment. Some definitions related to sustainable development have been emphasized by experts in this field, for example, Mark Mawhinney [27] in his book entitled Sustainable Development, categorizes the definition of sustainable development in three main categories of definitions. The first definition, which is the most widely referenced in various journals or papers, is Bruntland's definition [28], in which he defines it as "development that meets the present without compromising the ability of the future generations to meet their own need." Bruntland [28] emphasizes on the essential principles such as the principle of protection and guarantee for the needs of future generations so that one day they could still have the same choices as the present generation. The second definition is the one mentioned by the United Kingdom [10] which states that it is a "social progress that recognizes the needs of everyone, effective protection of the environment, prudent use of natural resources and maintenance of high and stable levels of economic growth and employment." In this definition, the three main dimensions (social, environmental and economic) are highly emphasized in achieving the vision of sustainable development. Furthermore, related indicators are also presented, such as social issues (poverty, life expectancy, crime rates in a region or country), the environment (pollution levels, emissions, animal populations, waste treatment), and economy (economic growth or GDP and employment opportunities for the community). Third, the definition proposed by Girardet [29] mentions that it is specifically in urban areas. He defines sustainable development as "a sustainable city organized so as to enable its citizens to meet their own needs and to enhance their well-being without damaging the natural world or endangering the living conditions of the other people, now or in the future." In general, in the three definitions above emphasize the importance of humans and the "equality" of humans and their surroundings (nature) both in the present and future.

However, one should also still recognize the debates of proper definition among experts despite the existing definitions expressed by experts. This can occur due to the differences in scientific backgrounds and school of thought of the experts mentioned above. Specifically in terms of schools of thought, this aspect can be categorized into three global perspectives: the perspectives of conservative economists who prioritize economic growth, the perspectives of environmental experts who prioritize environmental sustainability, and the experts with more moderate perspectives who try to mediate the other two perspectives. The definition that developed afterwards attempt to categorize the existing perspectives into main aspects which are known as the pillars of sustainable development including 'Environmental Protection', 'Social Equity', and 'Economic Well-being'. In 
subsequent developments, these three pillars of sustainable development are included in the dimensions of environmental protection, social development, and economic development [27], [30].

Campbell [31] explains sustainable development through the intersection of three ellipses describing three aspects, namely economic, social and ecological aspects [32]. This model was updated by Campbell, in which the intensity of each ellipse is more visible and more complete. Campbell's triangle model of sustainable development can be seen in the chart below.

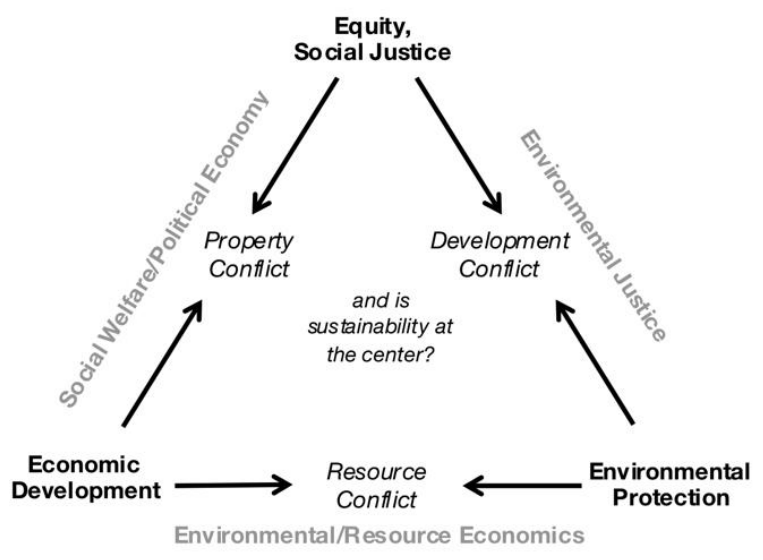

Fig 1. Campbell's Sustainable Development Model

Campbell uses a triangle model consisting of environmental protection, economic development, and equity as well as social justice. Campbell conducts a conflict analysis of the three dimensions. The analysis finds that 1) economy and environment create conflicting resources for economic interests and environmental interests, 2) environment and social justice create development conflicts between environmental protection interests and social justice, and 3) social justice and economy create property conflicts by considering Social Welfare or Political Economic [31]. Furthermore, Campbell explains that in its application it was difficult to find and reach an ideal model or find an ideal slice of the three aspects. It is difficult to reconcile the fulfillment of environmental justice with the economy. In reality, economic considerations are stronger than social and environmental considerations.

In global and national policies, the implementation of development principles can be seen through Sustainable Development Goals (SDG) stated in UN Resolution 70/1 entitled "Transforming our world: the 2030 Agenda for Sustainable Development."

SDGs is a global plan of action that aims to protect and build the planet and all living entities in it. Along with that, it is expected that welfare and peace development for all can be achieved in 2030. SDG consists of 17 goals supported by 169 targets that aim to measure the social, economic and environmental dimensions of sustainable development. The SDGs emphasize inclusion and fairness as well as to ensure that no one is left behind on the journey to a more sustainable development.

Children become one of the important subjects in SDGs. This is reflected in the objectives of the SDGs such as ending poverty in all its forms everywhere (SDG 1). This is because poverty is a risk factor for child development related to food and nutrition (SDG 2), health (SDG 3), education (SDG 4), child marriage (SDG 5), water and proper sanitation (SDG 6), and birth registration (SDG 16). Indonesian government is highly committed to the 2030 Agenda and has integrated SDGs into the national development planning process and is adapted the global indicators of SDGs into the Indonesian context. The government's commitment to implementing SDGs is reflected in the formation of the National SDG Coordinating Team supported by the SDG Secretariat. The 2015-2019 National Medium-Term Development Plan (Rencana Pembangunan Jangka Menengah Nasional/RPJMN) is made to be in line with SDGs, focusing on social development, economic development, environmental development, and access to justice and governance development. In addition, various efforts are also underway to mainstream SDG into the 2020-2024 RPJMN [33].

In the context of child labor as discussed in the previous chapter, it can be placed in the intersection of three pillars of sustainable development. In general, child labor in POS industry, which is more focused on economy, has clearly negated the fulfillment of children's rights and as the consequence, children lose the right 
of growth and development and lose the opportunities for better future. This clearly does not meet the principles and indicators of sustainable development. An interesting question is concerning the child labor in POS industry, which is the intersection of social, economic, and by also considering the inheritance of local knowledge. The results of the study described above show that child labor in traditional societies such as agriculture, plantations, and fishermen involving child laborers, which is included in the intersection of social, economic, and environmental considerations. This tradition does not only exist in Java but also in other regions in Indonesia. Effendi [34] explains that fishing communities have local wisdom to prepare children within the families of fishermen called "Anak Itik" (duckling). "Anak Itik" is an existing local wisdom and is a process for fisherman's children to become adults, understand the vastness of sea, and it becomes a culture that must be passed on from generation to generation. When the orientation of involving children focuses more on its economic aspects, violence is bound to happen to the children. They are no longer seen in social, economic, and environmental balance, rather, they are seen as laborers and are oriented to obtaining cheap labor costs.

However, Hunga's research [10] shows that female owner of batik industry and a female batik workerwho become the case study in her research - are the third generation of their respective families. Both are involved in batik work since they were eight years old. Both grew in a family with different social status; the first came from industry owner and the other one came from labor family. However, both of them grew up in a strong and batik tradition and having the ability to make batik is an obligation as a part of family identity. Both of them experienced the melting hot wax on their hands, learned to hold canting (tool to apply liquid hot wax), applying liquid hot wax on fabrics, and it was a gradual process until they were skilled and be reliable batik artists. In the midst of strong printed batik production, they still survived with traditional batik (written batik). However, due to poverty, children from labor families could not have higher education and then they choose to marry instead. The tradition of making batik is then continued by the third generation. In this case, they no longer work as laborers but instead they are entrepreneurs in micro-scale business. There is a change in social status from child labor to a micro-scale business owner. On the other hand, children from business owner can acquire higher education and have the opportunity to continue their parents' business. Based on these two cases, the early involvement of children through learning process and being involved as workers is seen as a learning process to have the skills, insights, and inheritance of batik cultural values.

From the several cases above, the involvement of workers is relevant if it is considered from the context of sustainable development to be able to critically explain the reality of child labor in a relatively varied industry, and tends to take increasingly informal forms and strategies. Home-based industry, integrated with the residential area, becomes a "hidden" area for child labor practices, which is untouchable by the child labor policies and regulations; therefore, many forms of violations of children's rights can easily occur. However, not all home-based industries are negative for children. Some positive cases of child labor is on POS-based industries whose products are based on local knowledge, with unique characteristics, and require inheritance for sustainability. Therefore, the involvement of children is an opportunity for children to learn, for character building, and the inheritance of local knowledge. However, commoditization will begin to occur when the involvement of children that initially focuses more on social, economic and environmental balance shifts more heavily to the economy. It will also cause marginalization, exploitation and violation of the children's rights.

If we return to Campbell's concept above and SDGs, we must look at child labor in POS industry through the intersection of three aspects namely social, economic and environmental, by also considering several SDGs' indicators related to child labor in the fulfillment of children's rights.

\section{Conclusion}

The phenomenon of child labor is a global and national phenomenon, and it has been happening for a long time. In some regions in Indonesia, child labor is part of a culture of education and a process of inheriting local knowledge and family identity. Child labor becomes increasingly complex due to the shift in orientation of employing children from its socio-cultural-environmental aspects towards a more economic one. Any forms of commercialization, marginalization, and exploitation of children become the basis for the enforcement of child protection, which is a global and national commitment. Even though the established legal basis and policies are already very clear, marginalization, exploitation and violations of the children's rights still occur. The implementation of strict rules on child labor in the formal sector does not prevent economic or industrial actors from seeking opportunities to recruit child workers in the informal sector. They enter the domestic sphere and use a house or family as a base for the production process in a POS-based industry. In this case, POS-based industry is both an opportunity and a problem because it is difficult to monitor since this area is not covered by the existing rules and policies. 
There are at least two findings related to the reality of child labor in POS-based industries. There are cases in which child workers tend to experience commoditization, marginalization, and exploitation when they are in POS-based industries that apply rapid production, mass production, with production targets, emphasizes on low wages, considers children as adult labor, unsafe working environment especially for children, and does not heed the fulfillment of workers' rights especially of children. However, there are also other cases in POS-based industries based on local knowledge, in which they have slow production, limited production, and child labor as a support within educational framework, character building, and inheritance of local knowledge; therefore, child labor is positive for sustainability. This is found in several industries such as traditional batik industry, weaving industry, handicrafts industry, and so on.

Child labor is relevant when viewed in the context of sustainable development to be able to critically explain the reality of child labor in a relatively varied industry and trends both in global and national scope, and for industries to take on increasingly informal forms and strategies. Child labor in POS industry is seen through the intersection of social, economic and environmental aspects. The involvement of children in industry, which is initially focused more on economic, social, and environmental balance, shifts heavily towards economy. As the result, commoditization will begin to occur, causing marginalization, exploitation, and also violation of children's rights. In principle, child labor is still considered as a child who needs protection and receives full support for better future as an important element of sustainability. Child labor can have positive meaning when it is done based on education, inheritance, and/or economic aspects. However, if child labor is placed as the center within the framework of the three aspects of SDGs, namely social, economic, and environmental, it should remain within the principle of protection and fulfillment of children's rights as future generations and sustainability in the future.

\section{References}

[1] Ministry of Women's Empowerment and Child Protection Republic of Indonesia, "Profil anak Indonesia," Jakarta, 2019.

[2] Badan Pusat Statistik, "Statistical yearbook of Indonesia," Jakarta, 2018.

[3] International Labour Organization, Findings on the worst forms of child labor: Required by the Trade and Development Act of 2015. Washington, DC: Bureau of International Labour Affairs, 2016.

[4] N. Wahyuni, "Tak ada kabar soal pekerja anak di Indonesia," Indonesian Institute, Jakarta, Jun-2019.

[5] T. Sudrajat, "Perlindungan hukum terhadap hak anak sebagai hak asasi manusia dalam perspektif sistem hukum keluarga di Indonesia," Kanun J. Ilmu Huk., vol. 13, no. 2, pp. 111-132, 2011.

[6] B. White, "Generational dynamics in agriculture: Reflections on rural youth and farming futures," Cah. Agric., vol. 24, no. 6, pp. 330-334, 2015.

[7] Direktorat Ketenagakerjaan dan Analisis Ekonomi, "Studi profil pekerja di sektor informal dan arah kebijakan ke depan," Jakarta, 2002.

[8] International Labour Organization, "Pekerja rumahan di Indonesia: Hasil dari penelitian pemetaan pekerja rumahan di Sumatera Utara, Jawa Barat, Jawa Tengah, Yogyakarta, Jawa Timur dan Banten,” Jakarta, 2015.

[9] A. I. R. Hunga, "Marjinalisasi perempuan dan risiko lingkungan dalam industri batik kimia: Urgensi batik ramah lingkungan dalam pembangunan berkelanjutan," Satya Wacana Christian University, 1999.

[10] A. I. R. Hunga, "Fenomena industri batik berbasis 'Putting-Out System' dalam pembangunan berkelanjutan dari perspektif gender: Studi kasus klaster industri batik di Jawa Tengah,” Satya Wacana Christian University, 2013.

[11] J. Peterson, P. F. Pearce, L. A. Ferguson, and C. A. Langford, "Understanding scoping reviews: Definition, purpose, and process," J. Am. Assoc. Nurse Pract., vol. 29, no. 1, pp. 12-16, 2017, doi: 10.1002/2327-6924.12380.

[12] H. M. L. Daudt, C. Van Mossel, and S. J. Scott, "Enhancing the scoping study methodology: A large, interprofessional team's experience with Arksey and O'Malley's framework," BMC Med. Res. Methodol., vol. 13, no. 1, pp. 48-56, 2013, doi: 10.1186/1471-2288-13-48.

[13] M. Dijkers, "What is a scoping study?," KT Updat., vol. 4, no. 1, pp. 1-5, 2011, doi: 10.1007/s00122-002-1183-y.

[14] International Labour Organization, "Findings on the worst form of child labor: Required by the Trade and Development Act 2017," Washington, DC, 2018.

[15] N. Nurhadi, "Child labour in rural Indonesia: Children and parents' perspectives," University of York, 2015.

[16] E. M. Agustine, Ishartono, and R. Resnawaty, "Kondisi pekerja anak yang bekerja di sektor berbahaya," Pros. KS Ris. PKM, vol. 2, no. 1, pp. 1-7, 2017.

[17] B. S. Iryani and D. S. Priyarsono, "Eksploitasi terhadap anak yang bekerja di Indonesia," J. Ekon. dan Pembang. Indones., vol. 13, no. 2, pp. 177-195, 2013.

[18] Ministry of Labour Republic of Indonesia, "Data dan informasi pekerja anak," Jakarta, 2016.

[19] T. Abebe, "Child labour in the global South: A review and critical commentary," Nor. Cent. Barneforsk., vol. 3, no. 4, pp. 11-28, 2009.

[20] L. Osment, "Child labour: The effect on child, causes and remedies to the revolving menace," University of Lund, 2014.

[21] Wahana Visi Indonesia, “Kasih peduli,” Wahana Visi Indonesia, Jakarta, 2016. 
[22] A. Priyambada, A. Suryahadi, and S. Sumarto, "What happened to child labor in Indonesia during the economic crisis: The trade-off between school and work.," Jakarta, 2005.

[23] N. E. Tadjuddin, Sumber daya manusia, peluang kerja, dan kemiskinan, 2nd ed. Jogjakarta: Tiara Wacana, 1995.

[24] A. Chua, Battle hymn of the tiger mother. Jakarta: Gramedia Pustaka, 2011.

[25] H. A. Darmarastri, "Pekerja anak di Surakarta masa kolonial: Dari pekerja keluarga menjadi pekerja upah," Sasdaya Gadjah Mada J. Humanit., vol. 2, no. 1, pp. 351-364, 2017.

[26] D. D. Prasetyo, "Pekerja rumahan Indonesia di bawah bayangan patriarki dan kapitalisme global," The Conversation, Jakarta, 2018.

[27] M. Mawhinney, Sustainable development: Understanding the green debates. Oxford: Blackwell Science, 2002.

[28] G. H. Brundtland, Our common future: The world commission on environment and development. Oxford: Oxford University Press, 1987.

[29] H. Girardet, Creating sustainable cities. Darlington, UK: Green Books, 1999.

[30] M. Hemmati and R. Gardiner, "Gender equity and sustainable development," 2002.

[31] S. D. Campbell, "Sustainable Development and Social Justice: Conflicting Urgencies and the Search for Common Ground in Urban and Regional Planning," Michigan J. Sustain., vol. 1, pp. 75-91, 2013, doi: 10.3998/mjs.12333712.0001.007.

[32] R. Riddell, Sustainable urban planning: Tipping the balance. Malden, MA: Blackwell Publishing, 2004.

[33] UNICEF Indonesia, "Roadmap of SDGs in Indonesia: A highlight," Jakarta, 2019.

[34] A. Y. Effendi, "Pekerja anak sebagai kearifan lokal," Habitus J. Pendidikan, Sosiologi, dan Antropol., vol. 2, no. 1, pp. 40-54, 2018. 